\title{
Steroid Cell Tumor of Ovary Not Otherwise Specified in A Child
}

\author{
Sushma NagsenRamraje, Arva Ali Pirosha* and Neha Matthew
}

Pathology Department, Grant Govt. Medical College \& Sir J.J. Group of Hospitals, Mumbai, India

\section{ABSTRACT}

Steroid cell tumour of the ovary is a very rare sex cord stromal tumour of ovary which commonly presents in women belonging to third and fourth decade of life.It usually manifests with a pelvic mass along with androgenic symptoms.

We present a case of 3 year old child, who presented with precocious puberty and hirsutism.Radiology was suggestive of ovarian mass for which oophorectomy was done. Gross, histopathological examination and immunohistochemistry proved it to be a steroid celltumour, not otherwise specified. Our case being unique because of presentation at merely 3 years of age.

\section{Keywords: Ovarian Tumors,Androgenic Manifestations}

\section{Introduction}

Steroid cell tumor of the ovary is a very rare ovarian neoplasm accounting for only $0.1 \%$ of all the ovarian tumors. ${ }^{[1,2]}$ The mean age of presentation is usually 43 years though it also reported at a young age. ${ }^{[1]}$ To the best of our knowledge, only 24 cases have been reported in literature of steroid cell tumor occurring in young age ranging from 2 to 12 years. ${ }^{[3]}$ The subtype, not otherwise specified is a sex hormone secreting variety with commonly androgenic manifestations. ${ }^{[1,4,9,10,1]}$ Here we present a case of a 3 year old girl who presented with complaints of abdominal pain, hirsutism, vaginal bleeding and development of secondary sexual features.

\section{Case Report}

A 3 year old girl was brought to the outpatient department with complaints of abdominal pain, vaginal bleeding and early development of breast, pubic and axillary hair since 2 months. On clinical examination the child had hyperpigmented linea nigra, hirsutism, breast bud Tanner stage II and well-developed hair in axilla and over labia. On Ultrasound examination a right adnexal mass measuring $7.3 \times 6.2 \times 4.3 \mathrm{~cm}$ was noted. Computed Tomography scan showed a large solid mass in right adnexa measuring $5.4 \times 6.6 \times 7.7 \mathrm{~cm}$ not seen separately from right ovary suggestive of neoplastic etiology, possibly a sex cord stromal tumor. On investigation the complete blood picture, thyroid profile and renal function tests, liver function tests and electrolytes were in normal range . Dehydroepiandrostenedione sulphate (DHEAS) level was 1500 microgram/deciliter, much higher than normal, serum lactate dehydrogenase (LDH) was mildly elevated and measured greater than 300IU/ml. Serum cortisol level and alpha feto protein (AFP) levels were within normal range i.e. $10.78 \mathrm{microgram} /$ deciliter and $3.26 \mathrm{IU} / \mathrm{ml}$ respectively. Serum follicle stimulating hormone(FSH) measured 0.46 $\mathrm{mIU} / \mathrm{ml}$, lower than the normal range, leutinising hormone (LH) was measuring $1.50 \mathrm{mIU} / \mathrm{ml}$ again lower than the normal range and beta human chorionic gonadotrophin hormone (beta HCG) was also low being $1.2 \mathrm{mIU} /$ ml.(Table 1)

Subsequently patient underwent oophorectomy and right ovarian mass was removed and sent for histopathological examination. On gross examination the mass measured $7.4 \times 4.5 \times 3.6 \mathrm{~cm}$ was well encapsulated circumscribed. Cut surface was yellowish, lobulated, homogenous and firm with no areas of haemorrhage or necrosis.(Fig 1\&2) On microscopic examination of haematoxylin and eosin stained slides, a tumour composed of sheets of polygonal cells with distinct cell borders(Fig 3) abundant clear foamy to granular eosinophilic cytoplasm, round nuclei and inconspicuous nucleoli was noted.(Fig 4) Capsular invasion, lymphovascular emboli, increased mitosis and necrosis were not seen. On immunohistochemistry, the tumour cells were positive for mic 2 and inhibin and wealy positive for calretinin while negative for AE1/AE3. Thus, the final diagnosis was given as steroid cell tumour of right ovary.

\section{Discussion}

The incidence of steroid cell tumours, not otherwise specified is highest in women during the third and fourth decades, but rarely postmenopausal women or children may also present with this tumour. ${ }^{[2,9]}$ Our case is rare because very few cases have been reported at a young age 
Table 1 : Various hormonal levels of the patient and it's comparison to the biological reference range.

\begin{tabular}{|c|l|l|l|}
\hline S.No & Type of the hormone & Normal range & Patient's value \\
\hline 1 & Dehydroepiandrostenedione sulphate (DHEAS) & $0-91$ & $1500 \mu \mathrm{g} / \mathrm{dl}$ \\
\hline 2 & Lactate dehydrogenase (LDH) & $3-21$ & $<300 \mathrm{IU} / \mathrm{ml}$ \\
\hline 3 & Serum cortisol & $0-5.5$ & $10.78 \mu \mathrm{g} / \mathrm{dl}$ \\
\hline 4 & Alpha feto protein (AFP) & $13.03-8.08$ (follicular phase) & $3.26 \mathrm{IU} / \mathrm{ml}$ \\
\hline 5 & Follicle stimulating hormone (FSH) & $0.46 \mathrm{mlU} / \mathrm{ml}$ \\
\hline 6 & Leutinising hormone (LH) & $12.39-6.6$ (follicular phase) & $1.50 \mathrm{mlU} / \mathrm{ml}$ \\
\hline 7 & Beta human chorionic gonadotrophin (beta HCG) & $0-5.3$ & $1.2 \mathrm{mlU} / \mathrm{ml}$. \\
\hline
\end{tabular}

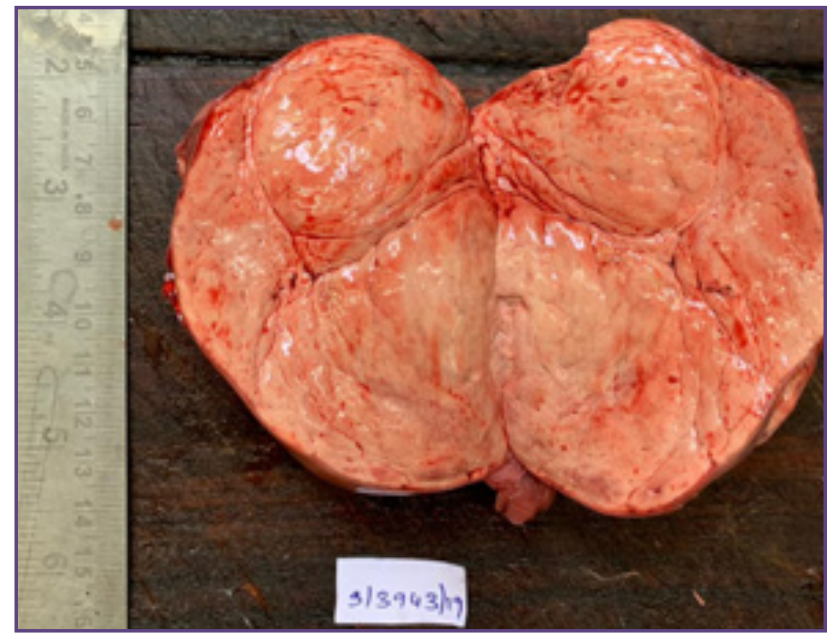

Fig. 1: Gross before fixation:Yellowish encapsulated, lobulated homogenous mass.

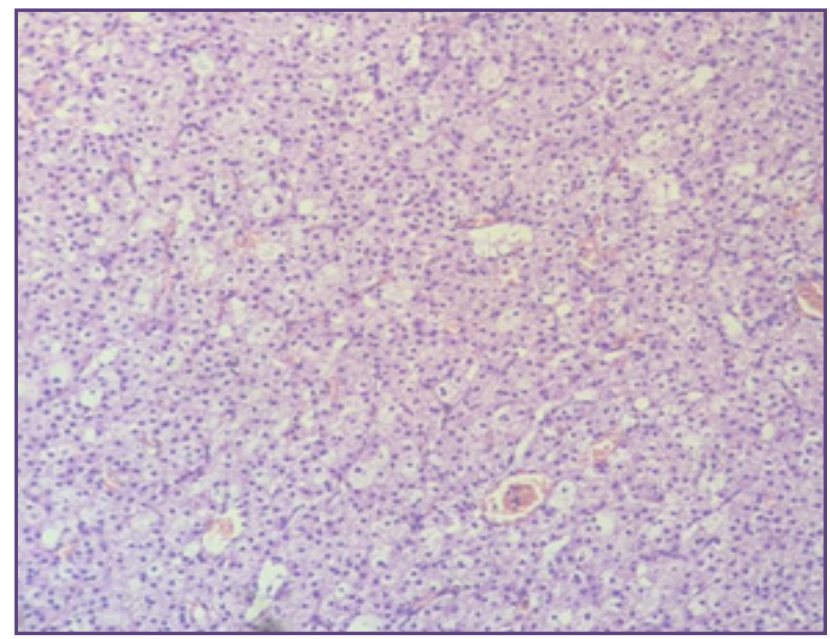

Fig. 3: Microscopy: Tumour composed of sheets of polygonal cells( $\mathrm{H} \& \mathrm{E}, 10 \mathrm{X})$.

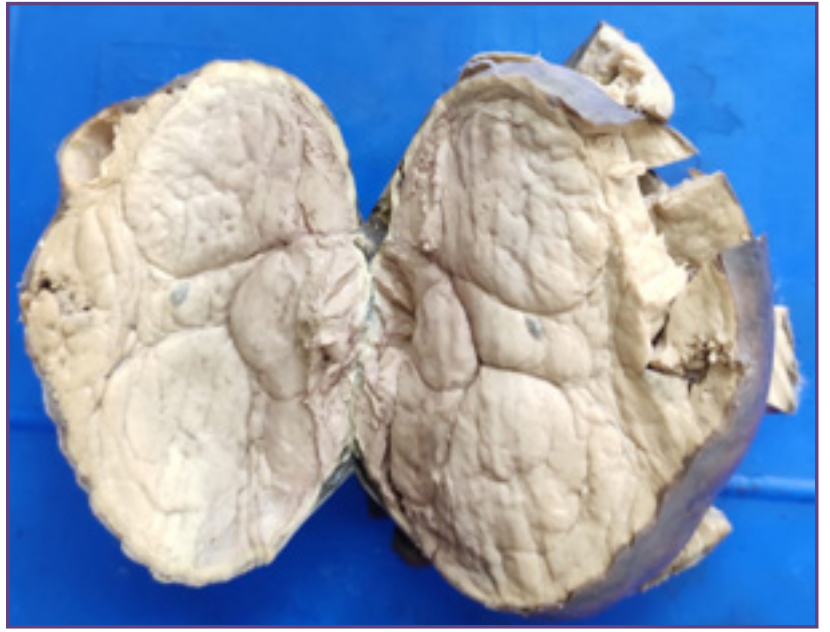

Fig. 2: After fixation:The tumour appears lobulated and homogenous.

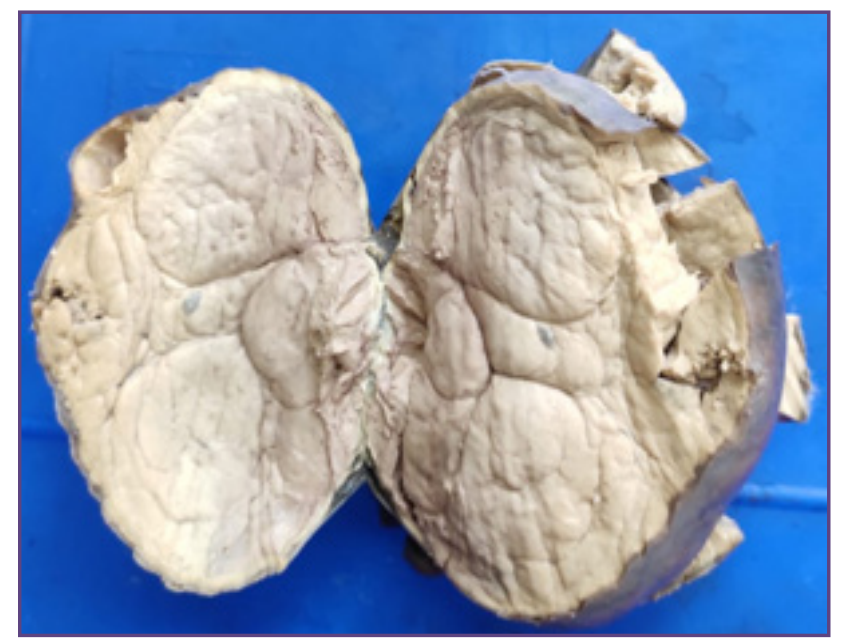

Fig. 4: Microscopy:Individualtumour cells with abundant foamy to clear eosinophilic cytoplasm, round nuclei and inconspicuous nucleoli(H\&E,40X). 
of 3 years. To the best of our knowledge youngest age of presentation of this tumour till date is 2.5 years and only 24 cases have been reported till date in the age range of 2.5 to 12 years. ${ }^{[3]}$ This tumour usually secretes hormones like androstenedione, $\alpha$-hydroxyprogesterone, and testosterone and thus shows androgenic manifestations like hirsutism and menstrual irregularities in postmenopausal and younger women and early development of secondary sexual characters i.e. precocious puberty in children. ${ }^{[1,4,9,11]}$ In our case the patient presented with vaginal bleeding, hirsutism and development of axilllary and pubic hair along with abdomino pelvic mass.

These tumours are of three types according to their cells of origin: stromal luteoma, leydig cell tumour and steroid cell tumour, not otherwise specified (NOS) which accounts for about $56 \%$ of steroid cell tumours. ${ }^{[2,10]}$ These tumours are well circumscribed, may be solid cystic or predominantly solid, with a characteristic yellowish appearance because of high lipid content. ${ }^{[4]}$ In our case the tumour was completely solid, lobulated and yellow in appearance. Histologically this tumour consists of diffusely arranged cells in nests, clusters, cords or columns. Individual tumour cells are round to polygonal with spongy to granular, eosinophilic cytoplasm with clear intracytoplasmic vacuoles. Tumour cells have distinct cell borders with central nuclei and prominent nucleoli, stroma being scanty, fibromatous, edematous or myxoid. These tumours may be benign or malignant, with the malignant counterpart being very very rare. They need to be differentiated from stromal luteoma and leydig cell tumours, stromal luteoma shows nodules of lutein type of cells in association with stromal hyperthecosis and focal degenerative changes forming pseudovascular and pseudoglandular spaces, while leydig cell tumour shows presence of cytoplasmic Reinke crystals and association with hyperplasia of leydig cells.$^{[10]}$ In our case on microscopy Reinke crystals, stromal hyperthecosis or pseudovascular or pseudoglandular spaces were not seen. On immunohistochemistry expression of inhibin in association with calretinin is helpful in making a diagnosis. [7] The histological parameters which predict a malignant behaviour of this tumour include size more than $7 \mathrm{~cm}$, mitosis more than 2/10 hpf, grade 2-3 nuclear atypia, necrosis and haemorrhage..$^{[4,6,8]}$ Our case had none of the above mentioned parameters and thus carried a benign behaviour with good prognosis. The treatment consists of complete removal of the tumour with total hysterectomy and bilateral salpingooophorectomy in post-menopausal women. Chemotherapy is required in malignant cases and cases with metastasis.

\section{Conclusion}

Steroid cell tumour not otherwise specified is a rare sex hormone producing tumour which needs to be differentiated from other sex cord stromal ovarian tumours and hormonally active tumours of the adrenal gland The most important point is to consider this tumour in the differential diagnosis of the ovarian hormonally active tumours even in younger patients of child bearing age and in children who present with precocious puberty. It has got characteristic gross and microscopic appearance with immunohistochemistry being an add on in the definitive diagnosis. The histological features need to be carefully evaluated for the presence of any malignant potential as further treatment and management of the patient depends on it.

\section{References}

1. Cserepes E, Szucs N, Patkos P, Csapo Z, Molnar F, Toth $\mathrm{M}$, et al. Ovarian steroid cell tumour and a contralateral ovarian thecoma in a postmenopausal woman with severe hyperandrogenism. Gynecol. Endocrinol. 2002;16(3):21316.

2. Qian L, Shen Z, Zhang X, Wu D, \& Zhou Y. Ovarian steroid cell tumor, not otherwise specified: A case report and literature review. Molecular and clinical oncology.2016 Dec, 5(6):839-841.

3. Dinc G, Saygin I, Kart C, Mungan S, Guven S, Seda Guvendag Guven E. A rare case of postmenopausal severe virilization: Ovarian steroid cell tumour, not otherwise specified. J Cases Obstet Gynecol. 2016;3(1):19-21.

4. Outwater EK, Wagner BJ, Mannion C, McLarney JK, Kim B. Sex cord-stromal and steroid cell tumours of the ovary. .Radiographics. 1998 Nov- Dec; 18(6):1523-46.

5. Hayes MC, Scully RE. Ovarian steroid cell tumours (not otherwise specified): A clinic-pathological analysis of 63 cases. Am J Surg Pathol. 1987;11(11):835-45.

6. Mehdi G, Ansari HA, Sherwani RK, Rahman K, Akhtar N. Ovarian Steroid Cell Tumour: Correlation of Histopathology with Clinico-pathologic Features. Pathology Research International. Volume 2011, Article ID 987895, 5 pages.

7. Rabban JT, Zaloudek CJ. A practical approach to immunohistochemical diagnosis of ovarian germ cell tumours and sex cord-stromal tumours. Histopathology. 2013 Jan;62(1):71-88.

8. Jiang W, Tao X, Fang F, Zhang S, Xu C. Benign and malignant ovarian steroid cell tumours, not otherwise specified: case studies, comparison, and review of the literature. Journal Of Ovarian Research. 2013,6:53.

9. Swain J, Sharma S, Prakash V, Agrawal NK, Singh SK. Steroid cell tumour: a rare cause of hirsutism in a female. Endocrinology, Diabetes and Metabolism case reports. September 2013;ID 13-0030. 
10. R.E. Scully . Ovarian tumours. A review. Am J Pathol. 1977 Jun;87(3):686-720.

11. Lee SH, Kang MS, Lee GS, Chung WY. Refractory
Hypertension and Isosexual Pseudoprecocious Puberty Associated with Renin-Secreting Ovarian Steroid Cell Tumor in a Girl. J Korean Med Sci. 2011 Jun;26(6):836-838.

*Corresponding author:

Dr. Arva Ali Pirosha, A/6, Princess Building, 139, R.B.Marg, Mumbai - 400003 INDIA

Phone: +91 9082400945

Email: arvapirosha@gmail.com

Financial or other Competing Interests: None. 